\title{
A data set of worldwide glacier length fluctuations
}

\author{
P. W. Leclercq ${ }^{1, *}$, J. Oerlemans ${ }^{1}$, H. J. Basagic ${ }^{2}$, I. Bushueva ${ }^{3}$, A. J. Cook $^{4}$, and R. Le Bris ${ }^{5}$ \\ ${ }^{1}$ Institute for Marine and Atmospheric research Utrecht, Utrecht University, Princetonplein 5, Utrecht, the Netherlands \\ ${ }^{2}$ Department of Geology, Portland State University, Portland, OR 97207, USA \\ ${ }^{3}$ Institute of Geography Russian Academy of Sciences, Moscow, Russia \\ ${ }^{4}$ Department of Geography, Swansea University, Swansea, SA2 8PP, UK \\ ${ }^{5}$ Department of Geography, University of Zürich, Zurich, Switzerland \\ *now at: Department of Geosciences, University of Oslo, P.O. Box 1047, Blindern, 0316 Oslo, Norway
}

Correspondence to: P. W. Leclercq (paul.leclercq@geo.uio.no)

Received: 11 September 2013 - Published in The Cryosphere Discuss.: 28 September 2013

Revised: 9 January 2014 - Accepted: 4 March 2014 - Published: 15 April 2014

\begin{abstract}
Glacier fluctuations contribute to variations in sea level and historical glacier length fluctuations are natural indicators of past climate change. To study these subjects, longterm information of glacier change is needed. In this paper we present a data set of global long-term glacier length fluctuations. The data set is a compilation of available information on changes in glacier length worldwide, including both measured and reconstructed glacier length fluctuations. All 471 length series start before 1950 and cover at least four decades. The longest record starts in 1535, but the majority of time series start after 1850 . The number of available records decreases again after 1962. The data set has global coverage including records from all continents. However, the Canadian Arctic is not represented in the data set. The available glacier length series show relatively small fluctuations until the mid-19th century, followed by a global retreat. The retreat was strongest in the first half of the 20th century, although large variability in the length change of the different glaciers is observed. During the 20th century, calving glaciers retreated more than land-terminating glaciers, but their relative length change was approximately equal. Besides calving, the glacier slope is the most important glacier property determining length change: steep glaciers have retreated less than glaciers with a gentle slope.
\end{abstract}

\section{Introduction}

Glaciers have been one of the main contributors to sealevel change during the last century (Gregory et al., 2013). Moreover, glaciers respond to changes in climate, translating the climatic signal into clearly observable changes in the landscape. Quantitative information on glacier fluctuations over previous centuries therefore provide long-term context for recently observed climatic changes of the last several decades (e.g., Oerlemans, 2005; Leclercq and Oerlemans, 2012; Lüthi, 2014). Measurements of glacier fluctuations can also be used to estimate the glacier contribution to sea-level rise (e.g., Lüthi et al., 2010; Glasser et al., 2011; Leclercq et al., 2011), and to assess the effect of glacier changes on mountain hydrology and fresh water availability (e.g., Liu et al., 2003; Bradley et al., 2006; Moore et al., 2009)

Of the glacier properties that can be measured to quantify glacier fluctuations (i.e., mass balance, volume, area, and length), information of glacier length fluctuations is the most abundant if we go further back in time (Cogley, 2009; Oerlemans, 2005; WGMS, 2012; and earlier volumes). Measurement programs were started as early as the 19th century (e.g., Forel and Pasquier, 1896), and for many glaciers around the world the length changes prior to the start of measurements can be derived from historical, geological, and biological evidence.

The combination of the different types of information on glacier length fluctuations across the globe has a large potential for the reconstruction of a worldwide picture of past glacier changes. In this paper we describe a data set of glacier 


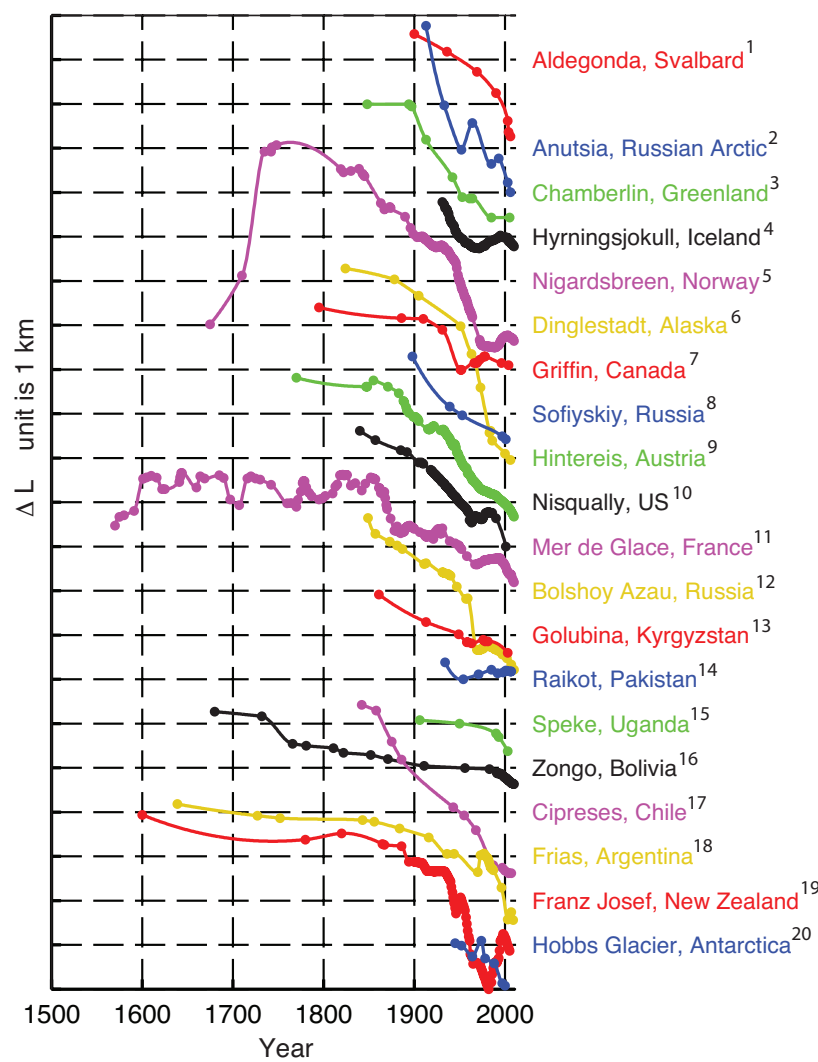

Fig. 1. Examples of glacier length records from different parts of the world. Each dot represents a data point. Data points are connected with Stineman interpolation. Data from WGMS (2012; and earlier volumes, and references therein), with additions from ${ }^{1}$ Glazovsky et al. (2009), I. Solovjanova, personal communication, 2006; ${ }^{2}$ Zeeberg and Forman (2001), this study; ${ }^{3}$ Yde and Knudsen (2007); 4 O. Sigurdsson, personal communication; $2008^{5}$ Østrem et al. (1977), Nesje et al. (2008), Nussbaumer et al. (2011); ${ }^{6}$ Weeks (2011), Wiles and Calkin (1994), Le Bris et al. (2011); ${ }^{7}$ Koch et al. (2009); ${ }^{8}$ De Smedt and Pattyn (2003); ${ }^{9}$ Beschel (1950), Greuell (1992), Fischer et al. (2013); ${ }^{10}$ Heliker et al. (1984), Granshaw and Fountain (2009); ${ }^{11}$ Nussbaumer et al. (2007); ${ }^{12}$ Laverov (2004), Panov (1993), Zolotarev (2009); ${ }^{13}$ Aizen et al. (2006); ${ }^{14}$ Schmidt and Nüsser (2009); ${ }^{15}$ Kaser and Osmaston (2002), Taylor et al. (2006); ${ }^{16}$ Rabatel et al. (2008); ${ }^{17}$ Araneda et al. (2009), Le Quesne et al. (2009); ${ }^{18}$ Villalba et al. (1990), Leclercq et al. (2012a); 19 McKinzey et al. (2004), Williams Jr. and Ferrigno (1989), B. Fitzharris, personal communication, $1993 ;{ }^{20}$ Cook et al. (2005).

length fluctuations that combines different sources of information. It has been constructed over the course of several years (Klok and Oerlemans, 2004; Oerlemans, 2005) and contains information of worldwide glacier length changes in a uniform format. Using the presented data set, we analyze the temporal evolution of the observed global glacier length changes, including a regional differentiation, and we analyze how length changes are related to the glacier geometry and the climate setting of glaciers.

\section{Data set description}

\subsection{Glacier length data}

The data set includes the length record of 471 glaciers (see Supplement for details and Fig. 1 for examples). In this article the term glaciers includes all perennial surface land ice masses (varying from small cirque glaciers, valley glaciers, to the outlets of large ice caps and ice fields), except for the ice sheets of Greenland and Antarctica. We also include glaciers on Greenland and Antarctica that are not part of, or attached to, the main ice sheets. Because the main goal of the glacier length data set is to study long-term glacier fluctuations, we have only included length records that start before 1950 and extend over several decades. The shortest time series in the data set covers 40 years, the longest 450 years. The variations of glaciers known to be surging are excluded, as these length changes are not climate driven and not representative for a larger sample of glaciers (Kamb et al., 1985; Yde and Knudsen, 2005). To a lesser extent, this is also the case for calving glaciers. In particular for large tidewater glaciers, the glacier bed topography can be of large influence in the glacier response to climate (e.g., Nick, 2006; Vieli and Nick, 2011). The original goal of the data set was the reconstruction of climate (Klok and Oerlemans, 2004; Oerlemans, 2005), hence only a few calving glaciers were included. However, the recorded changes in glacier length can be used to reconstruct the glacier contribution to sealevel rise (Oerlemans et al., 2007; Leclercq et al., 2011). The retreat of calving glaciers forms a substantial part of the glacier contribution (Cogley, 2009; Gardner et al., 2013) and therefore, the length records of 85 tidewater glaciers and 19 glaciers calving in fresh water (mostly outlets of the Patagonian ice fields) are included.

The backbone of this data set are the measurements of frontal positions published by the World Glacier Monitoring Service in the Fluctuations of Glaciers (www.wgms.ch) (WGMS, 2012; and earlier volumes, and references therein). The WGMS has a scientific collaboration network consisting of more than 30 national correspondents, who report the glacier observations in their country. These observations vary from annual to decadal front position changes. The measurement methods can be field measurements, often done by volunteers, as well as observations based on remote sensing.

Unfortunately, not all available information is included in the WGMS data base. Some observations were simply not reported and until recently, the WGMS collected only direct observations of frontal positions. Our knowledge of glacier fluctuations before the measurement programs started (i.e., before 1850 at best) consists solely of reconstructions from historical and geomorphological evidence. Recently, the WGMS started to include reconstructed front variations, and published 26 detailed records in Europe and South America (Zemp et al., 2011) as a first step toward standardizing reconstructed fluctuations of glaciers. However, far 
more information on glacier fluctuations exists, therefore we have extended the WGMS Fluctuations of Glaciers data set with relevant (quantitative) information of changes in glacier length. The additional information we used is based on numerous scientific articles and is complemented by annual reports, expedition reports, websites of glacier monitoring programs, and personal communication (see Supplement Table S2 for references to the sources used).

Historical sources in reconstruction include pictures (i.e., paintings, sketches, early photographs) as well as written documents, such as those about the advances over farmland of Glacier des Bossons and Nigardsbreen (Østrem et al., 1977; Bogen et al., 1989; Nussbaumer and Zumbühl, 2012). For the European glaciers there is a wealth of documents, resulting in long and detailed glacier length records (e.g., Zumbühl, 1980; Nussbaumer et al., 2007, 2011). Historical information is less abundant in other regions of the world, but on several occasions historical information could be used for the reconstruction of glacier fluctuations. To give a few examples, early military maps were used to determine 19th century glacier outlines in the Caucasus (Panov, 1993), written accounts from pioneers form a valuable addition to other sources for Cipreses glacier (Araneda et al., 2009) and Glaciar Frías (Villalba et al., 1990), both located in South America, and photographs were used to derive the fluctuations of Stocking Glacier, New Zealand (Salinger et al., 1983). The accuracy of the interpretation of these historical sources depends on the accuracy of descriptions and drawings. It also depends on the landscape around the glacier terminus. Some distinct features in the landscape are needed to connect the historical position to the present-day geometry. To conclude, the date of the historical source has to be determined.

Geomorphic evidence from glacial erosion and deposition provides important information about past glacier extents. The most frequently used geomorphological features are the lateral and terminal moraines, which are often preserved and indicate a former maximum glacier extent (e.g., Zumbühl and Holzhauser, 1988; Evison et al., 1996; Sawaguchi et al., 1999; Beedle et al., 2009). These moraines can be dated, which is mostly done with dendrochronology or lichenometry. In general, the uncertainty in glacier length reconstructions based on geomorphological evidence is due to the inaccuracy in the dating rather than uncertainty in the position. When using dendrochronology, the age of trees growing on moraines is measured from the tree rings. For living trees the age is simply measured by counting the tree rings. In the case of fossil wood the ring profile has to be matched to a regional tree-ring chronology. The estimated tree age gives the minimal age of the moraine, to which an estimate of the time needed for a tree to start growing has to be added to obtain the actual age of the moraine. This so-called ecesis time, missing tree rings, and the error when the sampled tree is not the oldest, are the main sources of uncertainty of the dendrochronological dating, which is typically in the range of 20-40 years (e.g., Villalba et al., 1990; Luckman, 2000; Koch and Kilian, 2005). In addition to the dating of moraines, occasionally trees are found that have been overridden or damaged during a glacier advance (Wiles and Calkin, 1994; Nesje et al., 2008). In the case of lichenometry the age of a moraine is estimated from the size of lichens growing on the boulders on the moraine, in combination with a typical growth rate (e.g., Evison et al., 1996; Rabatel et al., 2005; Solomina et al., 2010). This dating is in general less accurate than dendrochronology, with an uncertainty of 25-60 years. Occasionally, other geological evidence, in combination with other dating methods, is used, such as the influence of glacial run-off on peat in the glacier forefield with a chronology based on radio carbon dating (Espizúa and Pitte, 2009).

We have assigned the method of data acquisition to each data point of the glacier length fluctuations. Because of the large variety in methods, we use five categories: (1) direct measurements, (2) historical sources, (3) dendrochronological dating, (4) other dating methods, (5) method unknown. Category 1 (direct measurements of the glacier terminus position) includes field measurements, with or without GPS, (aerial) photography designed for the purpose, and satellite observations. These measurements have a typical spatial uncertainty of less than $50 \mathrm{~m}$ and a time accuracy within 1 year (Hall et al., 2003). Category 2 (historical sources) contains all data points derived from historical documents such as sketched maps from pioneers, pictures, paintings, and written descriptions. From the source literature discussed above, we found a typical uncertainty range of 100-200 m. In general the uncertainty increases further back in time. Dating is considered accurate to within 1 year. Glacier positions derived from geomorphological evidence, dated with dendrochronology, are put in the third category. The positions are mostly accurately measured (uncertainty of $50 \mathrm{~m}$ ), but the main uncertainty stems from the dating with an uncertainty of 2040 years. The fourth category includes geomorphological and other geological evidence dated from other, less accurate, methods - e.g., lichenometry and radiocarbon dating. The uncertainty of the dating strongly varies with the method used, but is in the order of 50 years. A fifth category contains all data points for which the method of measurement is unknown, and therefore the accuracy is also unknown.

\subsection{Additional glacier information}

As can be seen in the examples of the glacier length records in Fig. 1, there are few records with annual observations from the first to the last data point. In order to get annual values for the entire period covered by the record, which are needed for several applications of the data set (e.g., climate reconstruction), gaps in the records are interpolated using Stineman interpolation (Stineman, 1980; Johannesson et al., 2009, see Fig. 1 for examples of interpolated records). In this method, interpolated values are calculated from the values of the data points and the slopes of the record at the data points. The 
interpolated curve passes through the data points with a slope that is calculated from the circle passing through the point itself and the point before and after it. The Stineman interpolation works well for series with uneven spacing between data points, as is the case with the glacier length records. Moreover, it has the advantage that it produces no spurious minima or maxima.

Besides the length fluctuations, the data set includes additional information about the glaciers: the glacier name; the maximum, minimum and, if available, the median elevations; the length of the main flowline in the reference year 1950; the glacier area; the glacier location in latitude-longitude; calving, with a distinction between tidewater calving and calving in lakes; and the average annual precipitation on the glacier.

The data on the glacier geometry and location are often given in the same sources as the length fluctuations. For a large number of glaciers, information of geometry and location is also available in the World Glacier Inventory (WGMS and NSIDC, 1989, updated 2012). The latitude and longitude are given in degrees with a precision of two decimals, although the accuracy does vary. The geometry of a glacier changes over time and measurements of glacier area and length are made in different years for different glaciers. Regarding the glacier length, this is taken into account by calculating the glacier length changes between $1950\left(L_{1950}\right)$ and the year of measurement. If the record has no data point in 1950 , the length in 1950 is calculated from the interpolated length record. The glacier area is not adjusted.

We have included the annual precipitation to be able to take the climatic setting of the glacier into account. We use the climatological annual precipitation at the mean altitude of the glacier. The reference period over which the climatological average is determined differs for the different glaciers, but the reference period is not documented. When in situ measurements are lacking, values are estimated from climatologies (e.g., Zuo and Oerlemans, 1997, ERA reanalysis), regional climate models (e.g., Ettema et al., 2009), or nearby weather stations. The majority of the weather stations are situated at lower elevations than the elevation of the glacier. In these cases an estimate of the surplus precipitation at the glacier altitude, often based on expert judgement by the glaciological investigators of the particular glacier, is added to the measurements.

\subsection{Spatial and temporal coverage}

Figure 2 shows the global distribution of the 471 glacier length records. The glaciers included are found on all continents and virtually all latitude zones. The glaciers are, not surprisingly, strongly clustered in the major mountainous regions and we have divided them into 19 regions (Fig. 2). By combining some of these regions, the divisions match with the first-order regions of the Randolph Glacier Inventory (RGI, Arendt et al., 2012), where we have combined RGI regions 13-15 into one region, High Mountain Asia (HMA), following Gardner et al. (2013). The data set covers many of the glacierized regions on earth, but there are relatively few records from regions with a large glacier coverage (Alaska, islands of the Arctic Ocean, Antarctic periphery). In contrast, a wealth of information exists in Europe (Scandinavia, Pyrenees, Alps, Caucasus). This point is further illustrated in Fig. 3, where we have compared the regional distribution of the records with the distribution of the area covered by glaciers (the regional glacier-covered area is taken from the RGI). European glaciers are well represented in the data set, although these regions contain only a small fraction of the global glacier area. Also the low latitudes, West Canada and US, and the southern Andes are overrepresented in terms of their relative glacier-covered area. Due to the lack of glacier length records in the Canadian Arctic, a substantial part of the glacierized area on the globe is not represented by the length change data set.

As there is a large variety in the length of the different time series (Fig. 1), the number of available records changes strongly over time, as shown in Fig. 4. For the majority of the glaciers in the data set, the first available information is in the 19th century. This leads to a marked increase in the number of available records from 97 in 1850 to 288 in 1900. Going further back in time, the number of records decreases to 30 in 1700 , and there are none earlier than 1535 . The sharp increases in the early 1930s and mid-1940s result from the first aerial photography of Greenland (Bjørk et al., 2012), the Patagonian ice fields (López et al., 2010), and the Antarctic Peninsula (Cook et al., 2005). After 1962 the number of available records decreases again to 387 in 2000 and 311 in 2005. In a few cases the series end because of the disappearance of the glacier, but in most cases more recent data are not available because measurements have not been continued or reported.

Figure 4 also shows that prior to 1750 the Southern Hemisphere (SH) is as equally well represented in the data set as the Northern Hemisphere (NH), although the total number of records in the data set on the $\mathrm{NH}$ is much larger. During the 20th century, there is a reasonable number of records in the Arctic $\left(\geq 60^{\circ} \mathrm{N}\right)$. Prior to the mid-19th century however, information is limited, especially considering the large ice-covered area located at these high latitudes. Despite the small glacierized area in the Tropics, a substantial amount of information of tropical glacier fluctuations is available. Some information results from the reports of early explorers, whilst other data points originate from the dating of numerous terminal moraines (Rabatel et al., 2008).

Further back in time, not only the number of records decreases, but also the frequency of data points of the remaining records becomes lower, as can be seen from the examples in Fig. 1. Several length records in regions like Iceland, Norway, the Alps, and New Zealand have annual observations in the 20th century. Before 1880 however, no record has annual data, and length changes are mostly based on reconstructions rather than measurements. This leads to a lower frequency 


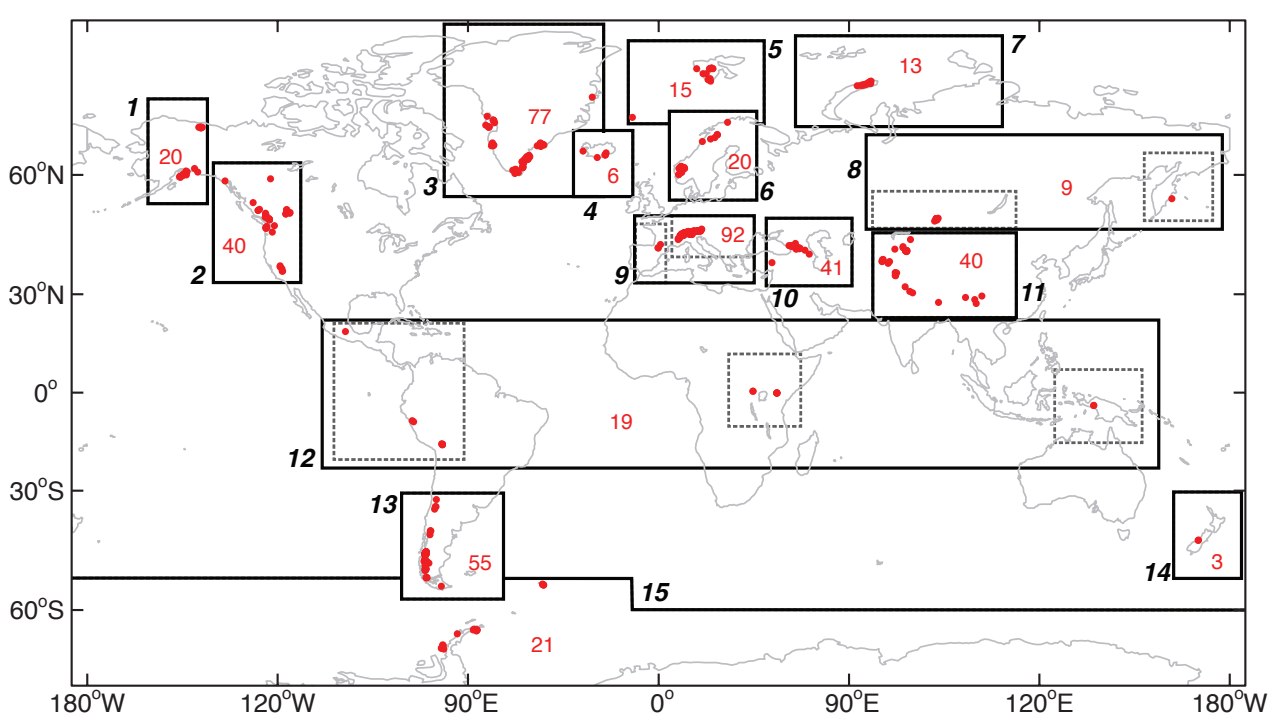

Fig. 2. Distribution of records over the world. In many cases the distance between the glaciers is so small that the dots overlap. The black boxes indicate the 15 first-order RGI regions, which in some cases are combinations of the regions defined in the data set (dashed grey boxes). The number inside the box (red) gives the number of records in the region, the number (italic, black) outside the box gives the number of the region (cf. Figs. 7, 9, Table 1).

Table 1. Characteristics of the glacier length records per region. The numbers of the regions correspond to the numbers in Fig. 2. It shows: the total number of length records in the region (No. records); the regional average number of data points per record (data points per record); the glacier area covered by the glaciers in the data set $\left(\operatorname{area}\left(\mathrm{km}^{2}\right)\right.$ ), including the area as percentage of the total glacier area in the region given by the RGI (\%total) and percentage of tidewater glacier area in the data set (\% TW); the average year of the first data point (start year), with the range of years in which the records start; the year the records of the region on average end (end year), again with the range; and the average regional length change (average $(\mathrm{km})$ ), with its standard deviation (SD $(\mathrm{km})$ ), and range (range $(\mathrm{km})$ ) over the period 1901-2000 ( $\Delta L$ 20th century). The standard deviation and range in the 20th century is only given for the glaciers that have data for the entire period 1901-2000.

\begin{tabular}{|c|c|c|c|c|c|c|c|c|c|c|c|}
\hline \multicolumn{3}{|c|}{ Region } & \multirow{2}{*}{$\begin{array}{r}\text { Data points } \\
\text { per record }\end{array}$} & \multicolumn{3}{|c|}{ Area } & \multirow{2}{*}{$\begin{array}{l}\text { Start year } \\
\text { average (range) }\end{array}$} & \multirow{2}{*}{$\begin{array}{l}\text { End year } \\
\text { average (range) }\end{array}$} & \multicolumn{3}{|c|}{$\Delta \mathrm{L} 20$ th century } \\
\hline no. & Name & No. records & & $\left(\mathrm{km}^{2}\right)$ & $\%$ total & $\% \mathrm{TW}$ & & & Average (km) & $\mathrm{SD}(\mathrm{km})$ & Range (km) \\
\hline 1 & Alaska & 20 & 10 & 1141 & 1.3 & 25 & $1844(1670-1910)$ & 1999 (1965-2009) & $-5.18 \pm 0.33$ & 6.84 & $-23.35--0.63$ \\
\hline 2 & W Canada \& US & 40 & 18 & 209 & 1.4 & 0 & $1876(1720-1935)$ & 1991 (1965-2007) & $-1.07 \pm 0.05$ & 0.60 & $-2.01--0.18$ \\
\hline 3 & Greenland & 77 & 7 & 1648 & 1.8 & 70 & $1910(1811-1939)$ & $2010(2005-2010)$ & $-1.30 \pm 0.04$ & 0.64 & $-2.61-0.00$ \\
\hline 4 & Iceland & 6 & 67 & 585 & 5.3 & 0 & $1822(1690-1932)$ & 2007 (1995-2010) & $-0.95 \pm 0.10$ & 0.16 & $-0.67--0.45$ \\
\hline 5 & Svalbard & 15 & 7 & 480 & 1.4 & 62 & $1899(1861-1936)$ & $2000(1975-2010)$ & $-1.48 \pm 0.17$ & 0.61 & $-2.31--0.48$ \\
\hline 6 & Scandinavia & 20 & 73 & 364 & 12.6 & 0 & $1846(1600-1917)$ & 2009 (2005-2010) & $-1.11 \pm 0.02$ & 0.81 & $-2.87--0.36$ \\
\hline 7 & Russian Arctic & 13 & 9 & 3204 & 6.2 & 100 & 1907 (1871-1913) & $2010(2006-2011)$ & $-6.91 \pm 0.15$ & 5.86 & $-11.23--2.95$ \\
\hline 8 & North Asia & 9 & 21 & 8 & 0.2 & 0 & $1860(1604-1936)$ & $1992(1962-2005)$ & $-1.14 \pm 0.12$ & 0.67 & $-1.74--0.79$ \\
\hline 9 & Central Europe & 92 & 94 & 806 & 38.4 & 0 & $1855(1535-1942)$ & 2008 (1978-2010) & $-0.94 \pm 0.01$ & 0.53 & $-2.71--0.17$ \\
\hline 10 & Caucasus & 41 & 22 & 274 & 24.9 & 0 & $1879(1839-1905)$ & 2002 (1987-2012) & $-0.81 \pm 0.04$ & 0.57 & $-2.42-0.03$ \\
\hline 11 & HMA & 40 & 11 & 1471 & 1.2 & 0 & $1888(1780-1943)$ & 1999 (1968-2010) & $-1.02 \pm 0.05$ & 0.54 & $-2.34--0.38$ \\
\hline 12 & Low Latitudes & 19 & 11 & 20 & 0.5 & 0 & $1810(1658-1932)$ & $2000(1990-2010)$ & $-0.64 \pm 0.06$ & 0.16 & $-0.73--0.29$ \\
\hline 13 & Southern Andes & 55 & 7 & 8744 & 29.7 & 29 & $1876(1594-1945)$ & 2004 (1983-2009) & $-3.12 \pm 0.09$ & 2.21 & $-9.06--0.50$ \\
\hline 14 & New Zealand & 3 & 70 & 68 & 5.7 & 0 & $1786(1600-1894)$ & 2005 (2001-2009) & $-1.22 \pm 0.05$ & 0.61 & $-1.71--0.53$ \\
\hline \multirow[t]{2}{*}{15} & Antarctica & 21 & 7 & 1656 & 1.2 & 97 & $1936(1882-1947)$ & 2001 (1996-2005) & $-1.15 \pm 0.16$ & 0.32 & $-0.63--0.18$ \\
\hline & Global & 471 & 31 & 20749 & 2.8 & 44 & $1876(1535-1947)$ & 2004 (1962-2012) & $-1.54 \pm 0.02$ & 2.30 & $-23.35-0.03$ \\
\hline
\end{tabular}

of data points: whereas before 1800 the number of available glacier length data points in 1 year never exceeds 6 , this number rapidly increases around 1900, peaking at 204 in 1981 (Fig. 5). It also means that in the period before 1900 both the temporal resolution as well as the spatial accuracy of the data points are lower than in the 20th century.
In Fig. 6 the distribution of the glacier length $\left(L_{1950}\right)$ over the glaciers in the data set is shown. Most of the glaciers are relatively small (41\% of the glaciers are shorter than $5 \mathrm{~km}$ ), but the data set also contains several large glaciers: $11 \%$ of the glaciers are longer than $20 \mathrm{~km}$. Compared to the length distribution of glaciers in the World Glacier Inventory 


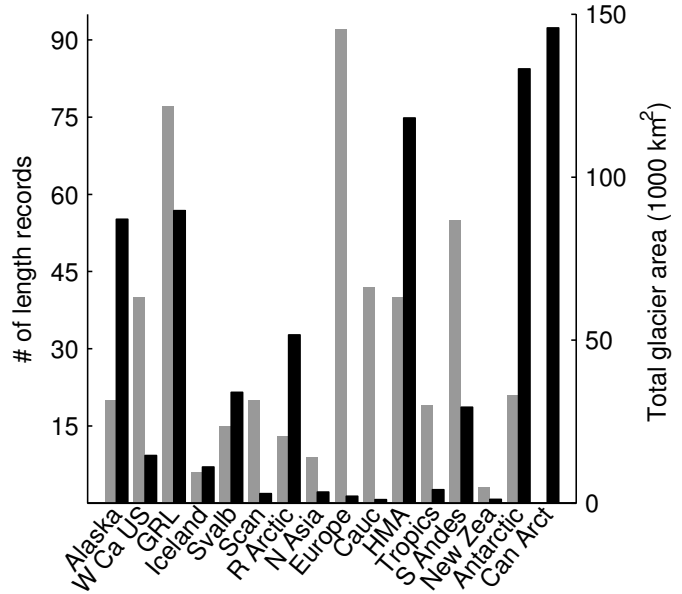

Fig. 3. Number of glacier length records per region (grey) and the total area covered by glaciers in this region, as given by the RGI (Arendt et al., 2012) (black). The regions correspond to Fig 2. Can Arct gives the glacier-covered area in the Canadian Arctic (regions 3 and 4 in the RGI), which is not represented in the glacier length data set.

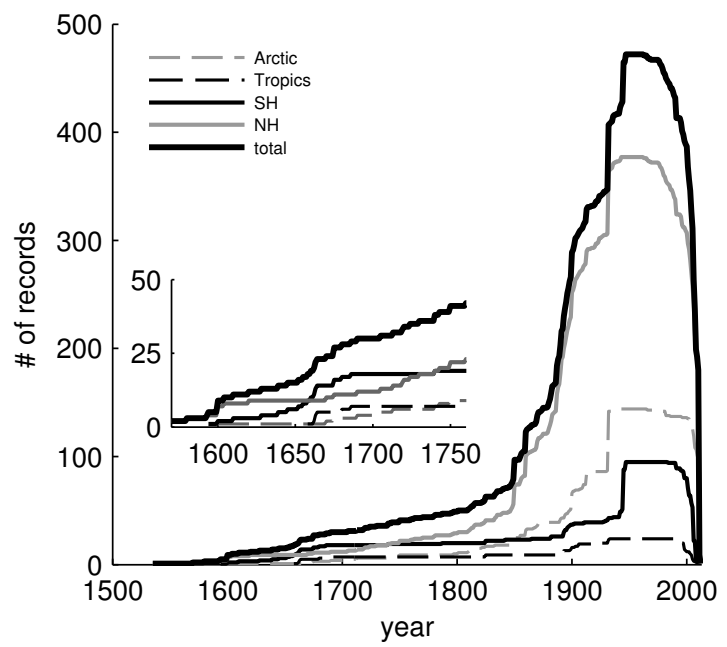

Fig. 4. Total number of glacier length records in time (thick black); number of records on the Southern Hemisphere (black) and Northern Hemisphere (grey). The number of records in the Tropics $\left(30^{\circ} \mathrm{S}\right.$ $\left.-30^{\circ} \mathrm{N}\right)$ and the Arctic $\left(\geq 60^{\circ} \mathrm{N}\right)$ are given in dashed black and grey, respectively. The inset enlarges the period 1570-1760.

(WGI, WGMS and NSIDC, 1989, updated 2012), our glacier length data set has a bias toward larger (i.e., longer) glaciers, indicating that observations and reconstructions of glacier length are biased towards large glaciers. Of the glaciers in the WGI, $96 \%$ are shorter than $5 \mathrm{~km}$ and only $0.3 \%$ are larger than $20 \mathrm{~km}$. The WGI contains the glacier length of more than 90000 glaciers and it is at present the most complete glacier inventory for this kind of information. This bias to-

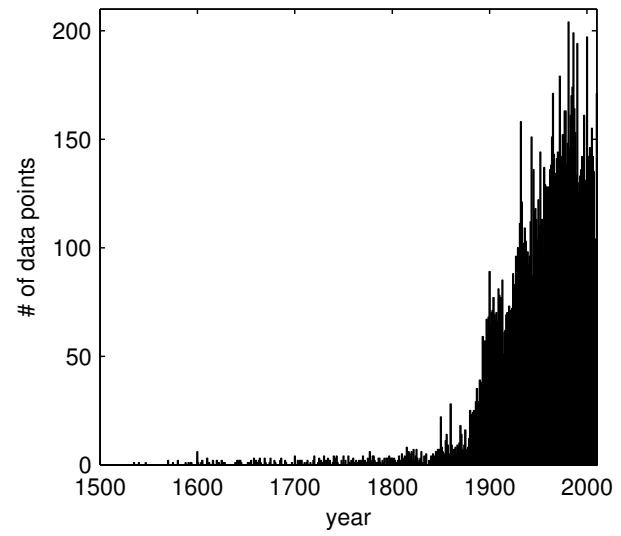

Fig. 5. Number of glacier length data points for each year in the period 1500-2010.

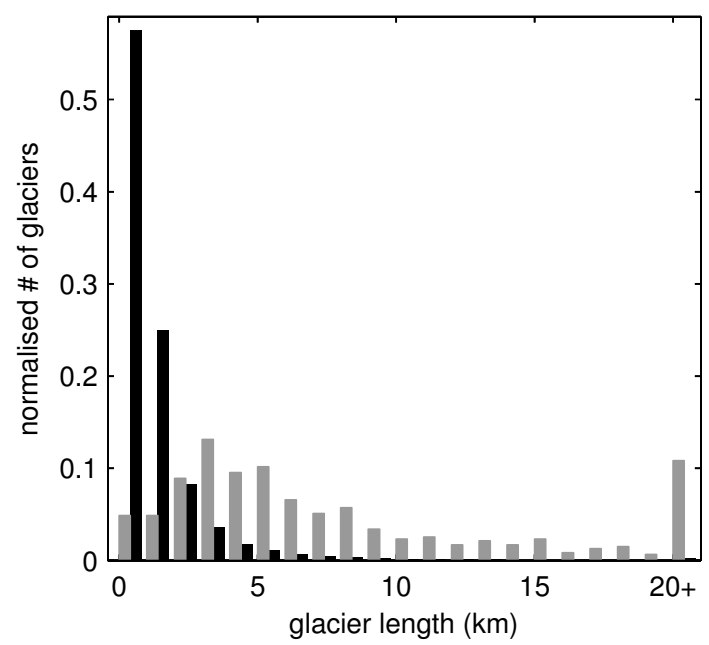

Fig. 6. Normalized distribution of glacier length in the glacier length fluctuations data set ( $L_{1950}$, grey) and the WGI (black). The rightmost bar of both data sets gives the relative number of glaciers with a length larger than $20 \mathrm{~km}$.

wards large glaciers in our data set is comparable with the available glacier mass balance measurements (Cogley and Adams, 1998). It also explains why the glaciers in the data set cover $3 \%$ of the global glacier area (Table 1), while the number of glaciers in the data set is only $0.2 \%$ of the estimated number of glaciers worldwide.

\subsection{Regional differentiation}

There are large regional differences in the source of the length change data as well as the number of glacier length records, which also vary in time (Fig. 7). Here, we briefly discuss the most important regional characteristics of the available information of glacier length fluctuations. 


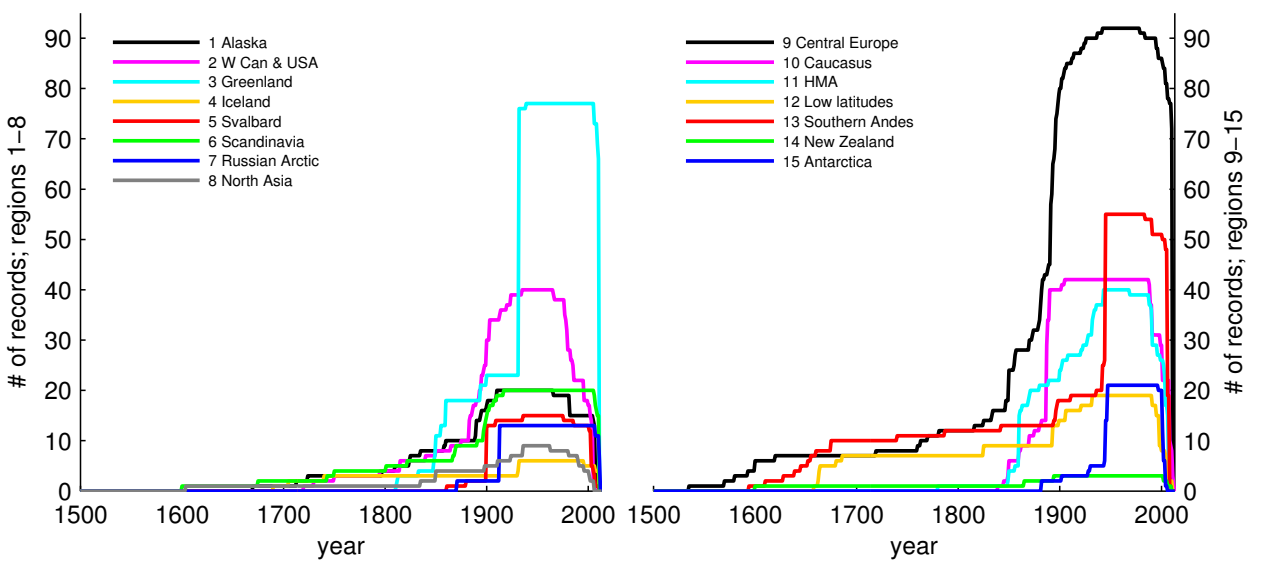

Fig. 7. Number of available glacier length records per region in time. The 15 regions are shown in two graphs for clarity.

\subsubsection{Alaska}

There are no records with annual data in Alaska. The data set includes records from the Arctic Brooks Ranges, as well as from glaciers along the maritime southern coast, including two tidewater glaciers and four lake-calving glaciers. The records are mainly based on geomorphological reconstructions extended with some data points from maps, aerial photography and satellite images since the mid-20th century (e.g., Wiles et al., 1999; Evison et al., 1996). Therefore, the average number of data points per record is relatively low, despite the fact that some of the records are considerably long (Table 1).

\subsubsection{West Canada and US}

There is a substantial amount of information from the Rocky and Coastal mountains in West Canada and the US. There are quite a few ongoing measurement programs and recent updates (e.g., Koutnik, 2009; Koch et al., 2009), but not all records in this region are up to date. Half of the records end between 1965 and 1985 .

\subsubsection{Greenland, Svalbard, and Novaya Zemlya}

The majority of the records in Greenland come from southeast Greenland, where Bjørk et al. (2012) mapped length changes since the 1930s from aerial photography and satellite observations. Longer time series exist in South and West Greenland, where historical information from the 19th century is available (Weidick, 1968; Yde and Knudsen, 2007). Eighteen glacier reconstructions from Weidick (1968) have been extended with Landsat images (Leclercq et al., 2012b). In Svalbard, less historical information is available. The longest record on Svalbard starts in 1861. Most of the records start around 1900, during the culmination of the Little Ice Age in this region (e.g., Rachlewicz et al., 2007). For No- vaya Zemlya the earliest information also originates from the late 19th century or early 20th century. Based on expedition reports, a map and satellite images, Zeeberg and Forman (2001) have reconstructed the length changes of 13 tidewater glaciers in north Novaya Zemlya for the period 1871/19131993. We have extended these time series of glacier length changes up to 2006-2011 (see Supplement for more details).

\subsubsection{Iceland, Europe and New Zealand}

Annual measurements throughout the 20th century exist in Iceland, the Alps, Scandinavia, and New Zealand (WGMS, 2012; and earlier volumes; Sigurdsson, 1998; Andreassen et al., 2005). These regions have frequent observations characterized by the high average number of data points per record (Table 1). Some of the monitored Icelandic glaciers show surging behavior and are therefore not included. For the Alps and Scandinavia there are also records with a high resolution prior to the 20th century, owing to the large amount of available historical information in these regions (e.g., Zumbühl, 1980; Zumbühl and Holzhauser, 1988; Nussbaumer et al., 2007, 2011). Central Europe has by far the most length records, but prior to 1800 the number of available records is comparable to the regions Southern Andes and low latitudes. This might change in the near future when the new compilation of reconstructions of Austrian glacier changes becomes available. This compilation is part of the current revision of the measurement records of Austrian glaciers (Fischer et al., 2013).

\subsubsection{Caucasus, High Mountain Asia, and North Asia}

The Caucasus has records that are fairly detailed with regular measurements since the Geophysical Year 1957 and additions from dated moraines (e.g., Bushueva and Solomina, 2012) and historical sources, such as the military maps from the 19th century (Panov, 1993). The region includes one 
record from Turkey (Sarikaya et al., 2009). In High Mountain Asia the number of records is limited considering the large glacierization of the Himalayas, Tien Shan, Pamirs, and other mountain ranges. Also the period covered by the time series is limited in this region. Most of the records start after 1850 and the longest record does not start until 1780. North Asia the has smallest percentage of regional glacier area in the data set (Table 1). As the number of length records is rather high with respect to the total glacierized area in the region (Fig. 3), it implies the glaciers in the data set are rather small. Like in High Mountain Asia, most length series in North Asia start relatively late, but there is one long (396 years) and relatively detailed record in Kamchatka (Sawaguchi et al., 1999). In 1990, many of the observations in the former Soviet Union cease, which leads to a notable drop in the number of available records.

\subsubsection{Low latitudes}

In the tropical part of the Andes, several very long glacier length records starting in the middle of the 17 th century are available from the lichenometric dating of moraines (Rabatel et al., 2005, 2006). In the other tropical regions the information on length changes does not extend this far back in time. The records in Africa all start around the beginning of the 20th century (Hastenrath, 1983; Taylor et al., 2006). The two records in Indonesia both start in 1825 when they where described in an expedition report (Williams Jr. and Ferrigno, 1989).

\subsubsection{Southern Andes}

Reconstructions of glacier length fluctuations have led to several long records in the southern Andes (e.g., Villalba et al., 1990; Koch and Kilian, 2005; Araneda et al., 2007; Masiokas et al., 2009). This region has the largest number of available records around 1700, although the reconstructions are generally not very detailed. The number of records in the southern Andes more than doubles in 1945. In this year, aerial photographs of the Patagonian ice fields were made (López et al., 2010) and a large number of outlet glaciers were mapped and included in the data set. The majority of these outlet glaciers are marine-terminating, which leads a substantial fraction of tidewater area and a large number of calving glaciers in this region.

\subsubsection{Antarctica}

The Antarctic region contains length records from glaciers on the subantarctic island of South Georgia and the peripheral glaciers of the Antarctic Peninsula. The time series of the glaciers on the peninsula are based on remote sensing (Cook et al., 2005) and are therefore short: they start in 1944 at best and most end in 2000 or 2001. The glaciers on South Georgia have longer records (Gordon and others, 2008). In the Antarctic region the fraction of tidewater glacier area is large.

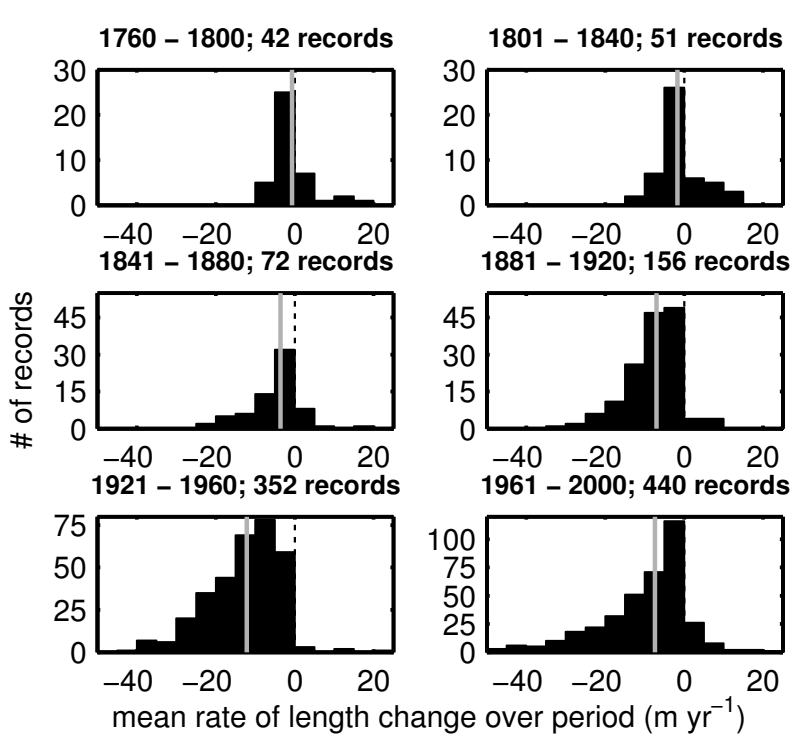

Fig. 8. Mean rate of length change $\left(\mathrm{m} \mathrm{a}^{-1}\right)$ of the available glacier length records for six 40-year periods between 1760 and 2000. The median rate of length change of all glaciers in that period is given by a grey line. Note the changing number of glacier length records for the different periods.

All included glaciers of the Antarctic Peninsula are tidewater glaciers, but some glaciers on South Georgia terminate on land.

\section{Glacier length fluctuations}

\subsection{Global and regional length change}

Figure 8 shows the average rate of length change of all glaciers in the data set for six 40-year periods between 1760 and 2000. In the periods 1760-1800 and 1801-1840, moderate retreats and advances occur to almost the same scale. Since the middle of the 19th century, the number of advancing glaciers is much smaller than the number of retreating glaciers, as indicated by the moderately to strongly negative median glacier length change, which indicates a global retreat of glaciers. Despite increasing global temperatures in the 20th century, this retreat is strongest in the period 19211960 rather than in the last period 1961-2000, with a median retreat rate of $12.5 \mathrm{myr}^{-1}$ in $1921-1960$ and $7.4 \mathrm{~m} \mathrm{yr}^{-1}$ in the period 1961-2000.

The regional averages of the change in glacier length are shown in Fig. 9a. For all regional averages, step changes in the regional average are frequent prior to 1900 . These step changes occur when additional records are added. Large jumps indicate that the mean of the glaciers is not representative for the glacier retreat in the region. After 1900 the samples are larger, making them more representative for the total of glaciers in the region. The regional averages display a very 
a)

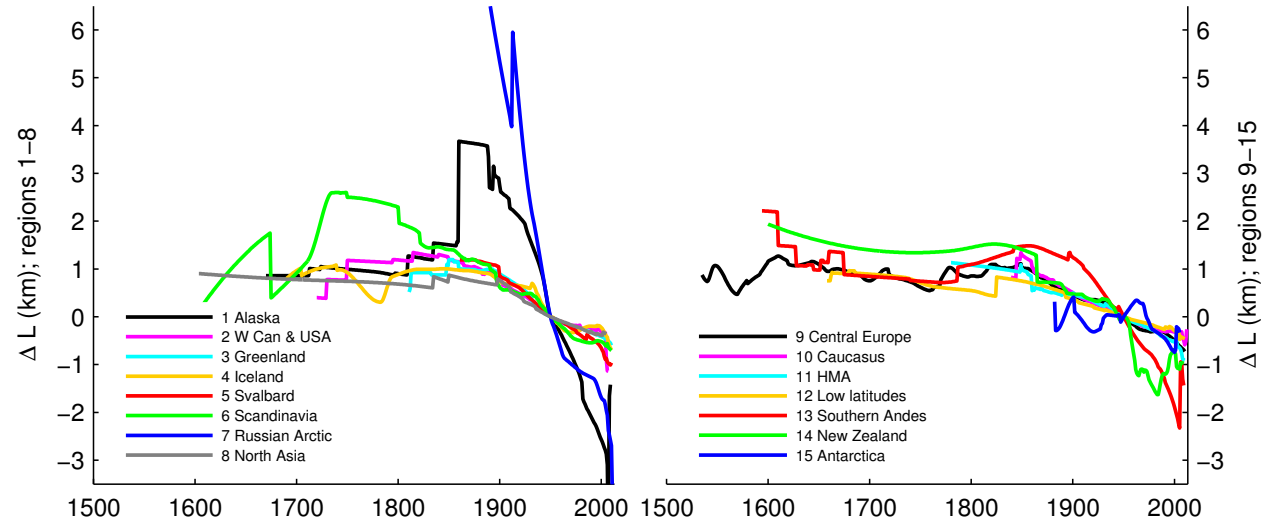

b)

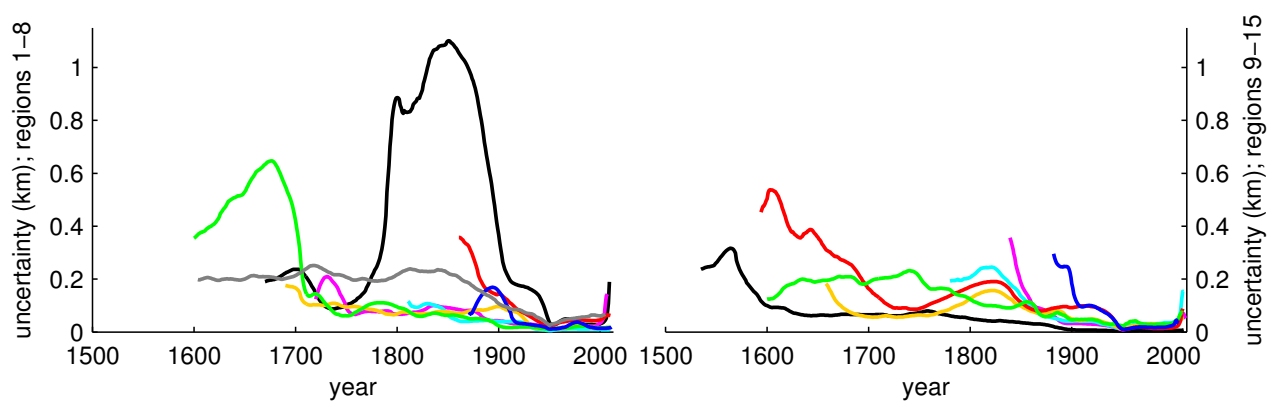

Fig. 9. (a) Regional changes in glacier length over time. For each region, the length change relative to $L_{1950}$ is averaged over the available records. The averages have jumps when a new record starts. In the 20th century most regional averages are smooth because the number of available records is larger (cf. Fig. 7). (b) Uncertainty in the regional average due to the uncertainty in the data points and interpolation. Colors of the lines in (b) correspond to those in (a).

coherent pattern confirming the global picture of small length changes until the mid-19th century and, since then, retreat of glaciers continuing up to present day. However, it should be noted not all fluctuations are included in the data set. For several long records the length changes in the period before the mid-19th century are based on dated moraines only. For these glaciers, intermediate retreats between the periods of maximum length, as indicated by the moraines, are not included in the reconstructions. This problem is largest for the regions North Asia (8), Low Latitudes (12), Southern Andes (13), and New Zealand (14). In the regions Alaska (1), Scandinavia (5), and Central Europe (9), intermediate retreats could also be reconstructed from historical sources and overridden trees.

We have calculated the uncertainty in the regional averaged length change from ensembles in which each ensemble member is the regional average of randomly perturbed glacier length records. The perturbed records are obtained by random spatial and temporal perturbations of the data points within their range of temporal and spatial uncertainty, and, in addition, by adding autoregressive noise to interpolated gaps in the records (see Leclercq and Oerlemans, 2012, for details). Each regional ensemble contains 100 members and the standard deviation of the ensemble, smoothed with a filter width of 21 years, is taken as the uncertainty of the regional average (Fig. 9b).

Typically, the uncertainty in the regional averages is less than $100 \mathrm{~m}$ in the 20th century and between 100 and $200 \mathrm{~m}$ before 1900. Notable exceptions occur for regional averages with large step changes, such as Alaska around 1860, Scandinavia around 1670 and Southern Andes in the first half of the 17th century. The step change in the regional average is caused by the start of a record that strongly deviates from the average of the rest of the records (in Alaska the length record of a tidewater glacier starts in 1860). As the first data point often has a temporal uncertainty, the timing of these step changes is different in the different ensemble members, which leads to a large uncertainty in the regional average for the period around the step change.

Averaged over all glaciers in the data set, the 20th century change in glacier length is $-1.56 \pm 0.03 \mathrm{~km}$, where the uncertainty is again based on a 100-member ensemble of global averages from perturbed length series. The length changes of the individual records that cover the 20th century vary from $-23.35 \mathrm{~km}$ (McCarthy, Alaska) to $+0.03 \mathrm{~km}$ (Chungurchatchiran, Caucasus), with a standard deviation of $2.31 \mathrm{~km}$ (Table 1). Hence, there is a significant variability in the length change of each glacier, and the differences 
a)

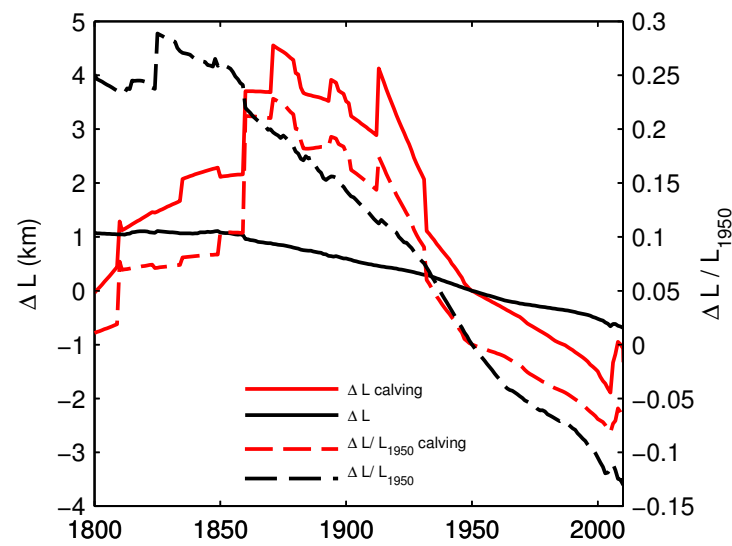

b)

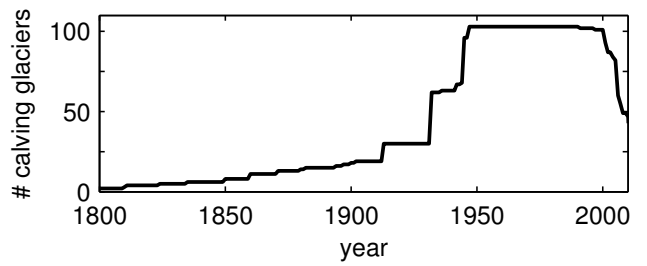

Fig. 10. (a) Global average length change with respect to 1950 of calving glaciers, both tidewater and calving in lakes, (red) and non-calving glaciers (black). The globally averaged relative length change ( $\Delta L$ divided by the glacier length in 1950) is given in dashed lines for both calving (dashed red) and non-calving (dashed back) glaciers (scale on right axis). (b) Number of calving glaciers in the data set as a function of time. Prior to \pm 1860 the number of calving glaciers is very small and the average length change is dominated by the large advance of San Rafael Glacier, Patagonia.

between glaciers of the same region are often larger than the differences between the regions.

\subsection{Dependence of length change on glacier properties}

In general, the averaged length changes of the different regions show a similar pattern and magnitude, with the exception of Alaska, the Russian Arctic, Southern Andes, and New Zealand, where the regional average length change is large in comparison with the other regions. The New Zealand average is dominated by the large fluctuations of Franz Josef glacier, a very sensitive glacier due to its maritime climate and geometry (Anderson et al., 2008). Alaska, the Russian Arctic, and Southern Andes include several large calving glaciers. On average, calving glaciers have had a much larger absolute retreat than the land-terminating glaciers in the data set, as shown in Fig. 10a. This is also reflected in the large range in the 20th century length changes in regions that include calving and non-calving glaciers (Table 1). However, the relative retreat of calving and non-calving glaciers has been very similar, at least after 1860, when the number of calving glaciers in the data set becomes larger (Fig. 10b). The Antarctica and Greenland regions differ from the global pattern. The calv- ing glaciers in the Antarctic region, 18 in the data set, have larger fluctuations than the land-terminating glaciers in this region ( 3 in the data set). However, the averaged net length change over the period for which we have data is limited for both types of glaciers. Surprisingly, the 37 calving glaciers in Greenland have on average nearly the same amount of length change as the 40 land-terminating Greenlandic glaciers. The relative length change of calving glaciers in Greenland is smaller than the relative length change of land-terminating glaciers.

Besides the effect of calving, the response of a glacier to changes in climate depends on its individual climatic setting and the glacier geometry (e.g., Oerlemans, 2001). According to theory, the surface slope of the glacier is the most important geometrical factor: steep glaciers are less sensitive to climate change than gently sloping glaciers (e.g., Oerlemans, 2001). Furthermore, glaciers situated in a wet temperate climate are more sensitive to climatic change than glaciers in a more continental climate. The correlation between slope and length change is confirmed by the observed glacier length changes over the 20th century: large retreats are rare for steep glaciers (Fig. 11a). Information on temperature is not included in the data set, but we can use the amount of precipitation as an indication of the climatic setting of the glaciers. The relationship between length change and precipitation is not very clear from the observations in the data set, but for glaciers in a wet climate small retreats $(<500 \mathrm{~m})$ have not been observed (Fig. 11b). The observed length fluctuations seem to have no clear correlation with latitude or glacier elevation. There are several reasons for the spread in Fig. 11a and b: (i) the relationship between length change and the glacier property is not corrected for the influence of other glacier properties; (ii) there are non-climatic processes causing changes in glacier length, such as the influence of the bed topography; and, (iii) there are regional differences in climate change over the 20th century.

\section{Concluding summary and outlook}

We have presented a data set of worldwide glacier length fluctuations, which combines measurements with different types of glacier length reconstructions. The data set contains the glacier length records for 471 glaciers and it covers the period 1535-2011. There are glacier length records from all continents and at almost all latitudes. Unfortunately, there are no records from the Canadian Arctic. The number of available records is strongly time-dependent. The number of available records is limited in the early 17 th century and only after the mid-19th century does the number of records increase significantly. Additional attribute information was assigned to each glacier (coordinates, precipitation, glacier area, maximum and minimum altitude) and glacier length measurement (measurement methods). 

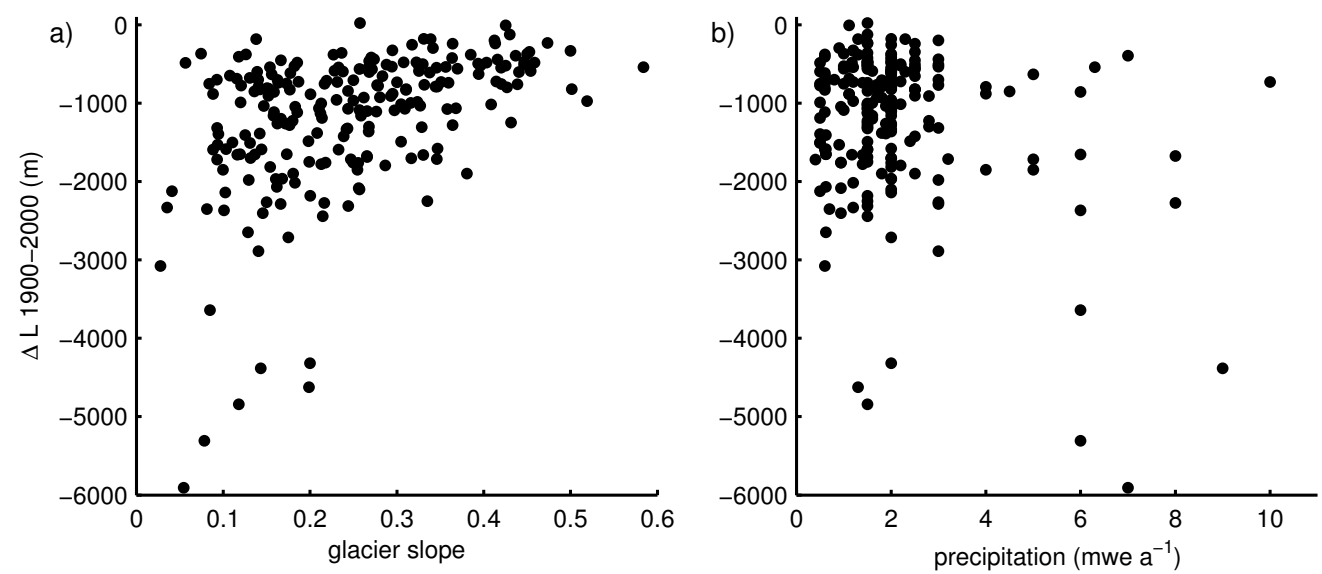

Fig. 11. Glacier length change (m) over the period 1900-2000 as a function of (a) the mean slope $\left(h_{\max }-h_{\min }\right) / L_{1950}$ of the glacier and (b) the precipitation on the glacier. The length change is only shown for the 227 records that entirely cover the period 1900-2000.

The available glacier length records show a coherent global glacier signal, of little length change in the 17th to mid-19th century, followed by a general retreat that continued throughout the 20th century. For the observed glaciers, the 20th century retreat was strongest in the first half of the 20th century. Despite these general global trends, the fluctuations of individual glaciers vary strongly, indicating that the characteristics of individual glaciers play an important role. In general, calving glaciers retreated more than landterminating glaciers, although the average relative change is similar for both glacier types. The observed retreat over the 20th century confirms that steep glaciers are less sensitive to climatic change than glaciers with a gentle slope.

This data set leaves ample room for improvement. First of all it would benefit from including records from regions with little or no coverage: northern Asia, Arctic islands of Russia and Canada and the Antarctic region. These regions contain a large proportion of the world's glacier volume, and by adding data from glaciers in these regions, the data set would better represent the global glacier fluctuations. Furthermore, as about $35 \%$ of the length records in the data set end before 2005, many of the included time series could be updated, e.g., by the analysis of satellite images as we have done for the records on Novaya Zemlya. The climatic reconstructions based on glaciers would benefit from more long-term and detailed length records, especially from regions outside of Europe and South America.

The data set presented in this paper has been included in the Supplement and the data are submitted to the WGMS.

Supplementary material related to this article is available online at http://www.the-cryosphere.net/8/659/ 2014/tc-8-659-2014-supplement.zip.
Acknowledgements. The authors thank all colleagues and volunteers who have contributed with dedication and commitment to the data on glacier length fluctuations in the data set. In particular, we would like to thank A. Bjørk, K. Brugger, C. Burrows, T. Chinn, M. Citterio, L. Espizua, H. Elvehøy, A. Fischer, I. Gärtner-Roer, A. Herrington, B. Hynek, T. Kerr, M. Kunz, S. Kutuzov, I. Lavrentiev, P. Lopez, A. Mackintosh, M. Masiokas, S. Nussbaumer, G. Osipova, D. Petrakov, P. Pitte, A. Rabatel, S. Schmidt, C. Schneider, O. Sigurdsson, O. Solomina, M. Sund, J. Yde, L. Weeks, A. Weidick, G. Wiles, J. Zeeberg, M. Zemp, and H. J. Zumbühl, who helped in collecting the available data and made their own data on changes in glacier length available. We also thank M. Maris for her help in assigning the method of acquisition and S. Lhermitte for his help in the analysis of satellite images of Novaya Zemlya. To conclude, we thank the anonymous reviewers for their comments that helped to improve the paper.

Edited by: G. Hilmar Gudmundsson

\section{References}

Aizen, V. B., Kuzmichenok, V. A., Surazakov, A. B., and Aizen, E. M.: Glacier changes in the central and northern Tien Shan during the last 140 years based on surface and remote-sensing data, Ann. Glaciol., 43, 202-213, 2006.

Anderson, B., Lawson, W., and Owens, I.: Response of Franz Josef Glacier Ka Roimata o Hine Hukatere to climate change, Global Planet. Change, 63, 23-30, doi:10.1016/j.gloplacha.2008.04.003, 2008.

Andreassen, L. M., Elvehøy, H., Kjøllmoen, B., Engeset, R. V., and Haakensen, N.: Glacier mass-balance and length variation in Norway, Ann. Glaciol., 42, 317-325, 2005.

Araneda, A., Terrejón, F., Aguayo, M., Torres, L., Cruces, F., Cisternas, M., and Urrutia, R.: Historical records of San Rafael glacier advances (North Patagonian Icefield): another clue to 'Little Ice Age' timing in southern Chile?, The Holocene, 17, 987-998, doi:10.1177/0959683607082414, 2007. 
Araneda, A., Torrejón, F., Aguayo, M., Alvial, I., Mendoza, C., and Urrutia, R.: Historical records of Cipreses glacier $\left(34^{\circ} \mathrm{S}\right)$ : combining documentary-inferred 'Little Ice Age' evidence from Southern and Central Chile, The Holocene, 19, 1173-1183, 2009.

Arendt, A., Bolch, T., Cogley, J., Gardner, A., Hagen, J.-O., Hock, R., Kaser, G., Pfeffer, W. T., Moholdt, G., Paul, F., Radić, V., Andreassen, L., Bajracharya, S., Beedle, M., Berthier, E., Bhambri, R., Bliss, A., Brown, I., Burgess, E., Burgess, D., Cawkwell, F., Chinn, T., Copland, L., Davies, B., De Angelis, H., Dolgova, E., Filbert, K., Forester, R., Fountain, A., Frey, H., Giffen, B., Glasser, N., Gurney, S., Hagg, W., Hall, D., Haritashya, U., Hartmann, G., Helm, C., Herreid, S., Howat, I., Kapustin, G., Khromova, T., Kienholz, C., Koenig, M., Kohler, J., Kriegel, D., Kutuzov, S., Lavrentiev, I., LeBris, R., Lund, J., Manley, W., Mayer, C., Miles, E., Li, X., Menounos, B., Mercer, A., Moelg, N., Mool, P., Nosenko, G., Negrete, A., Nuth, C., Pettersson, R., Racoviteanu, A., Ranzi, R., Rastner, P., Rau, F., Rich, J., Rott, H., Schneider, C., Seliverstov, Y., Sharp, M., Sigurdsson, O., Stokes, C., Wheate, R., Winsvold, S., Wolken, G., Wyatt, F., and Zheltyhina, N.: Randolph Glacier Inventory [v2.0]: a dataset of global glacier outlines, Global Land Ice Measurements from Space, Boulder, Colorado, USA, Digital Media, 2012.

Beedle, M., Menounos, B., Luckman, B. H., and Wheate, R.: Annual push moraines as climate proxy, Geophys. Res. Lett., 36, L20501, doi:10.1029/2009GL039533, 2009.

Beschel, R.: Flechten als Altersmasstab rezenter Moranen, Zeitschrift für Gletscherkunde und Glazialgeologie, 1, 152-161, 1950.

Bjørk, A. A., Kjær, K. H., Khan, N. J. K. S. A., Kjeldsen, K. K., Andresen, C. S., Box, J. E., Larsen, N. K., and Funder, S.: An aerial view of 80 years of climate-related glacier fluctuations in southeast Greenland, Nature Geosci., 5, 427-432, doi:10.1029/2005GL023962, 2012.

Bogen, J., Wold, B., and Østrem, G.: Historic glacier variations in Scandinavia, in: Glacier fluctuations and climate change, edited by: Oerlemans, J., 109-128, Kluwer Academic Publishers, 1989.

Bradley, R. S., Vuille, M., Diaz, H. F., and Vergara, W.: Threats to Water Supplies in the Tropical Andes, Science, 312, 1755, doi:10.1126/science.1128087, 2006.

Bushueva, I. S. and Solomina, O. N.: Fluctuations of Kashkatash glacier over last 400 years using cartographic, dendrochronologic and lichonometric data, Ice and Snow, 2, 121-130, 2012.

Cogley, J. G.: Geodetic and direct mass-balance measurements: comparison and joint analysis, Ann. Glaciol., 50, 96-100, 2009.

Cogley, J. G. and Adams, W. P.: Mass balance of glaciers other than the ice sheets, J. Glaciol., 44, 315-325, 1998.

Cook, A. J., Fox, A. J., Vaughan, D. G., and Ferrigno, J. G.: Retreating Glacier Fronts on the Antarctic Peninsula over the Past HalfCentury, Science, 308, 541-544, doi:10.1126/science.1104235, 2005

De Smedt, B. and Pattyn, F.: Numerical Modelling of historical front variations and dynamic response of Sofiyskiy glacier, Altai mountains, Russia, Ann. Glaciol., 37, 143-149, 2003.

Espizúa, L. E. and Pitte, P.: The Little Ice Age glacier advance in the Central Andes $\left(35^{\circ} \mathrm{S}\right)$, Argentina, Palaeogeogr. Palaeoclimatol. Palaeoecol., 281, 345-350, 2009.

Ettema, J., van den Broeke, M. R., van Meijgaard, E., van de Berg, W. J., Bamber, J. L., Box, J. E., and Bales, R. C.: Higher sur- face mass balance of the Greenland ice sheet revealed by highresolution climate modeling, Geophys. Res. Lett., 36, L12501, doi:10.1029/2009GL038110, 2009.

Evison, L. H., Calkin, P. E., and Ellis, J. M.: Late-Holocene glaciation and twentieth-century retreat, northeastern Brooks Range, Alaska, The Holocene, 6, 17-24, 1996.

Fischer, A., Patzelt, G., and Kinzl, H.: Length changes of Austrian glaciers 1970-2011, Pangaea, doi:10.1594/PANGAEA.821823, 2013.

Forel, F. A. and Pasquier, L. D.: Les variations périodiques des glaciers. Ier Rapport, 1895, Extrait des Archives des Sciences physiques et naturelles, 1-2/4, 218-245, 1896.

Gardner, A. S., Moholdt, G., Cogley, J. G., Wouters, B., Arendt, A. A., Wahr, J., Berthier, E., Hock, R., Pfeffer, W. T., Kaser, G., Ligtenberg, S. R. M., Bolch, T., Sharp, M. J., Hagen, J. O., van den Broeke, M. R., and Paul, F.: A Reconciled Estimate of Glacier Contributions to Sea Level Rise: 2003 to 2009, Science, 340, 852-857, doi:10.1126/science.1234532, 2013.

Glasser, N. F., Harrison, S., Anderson, K. N., and Cowley, A.: Global sea-level contribution from the Patagonian Icefields since the Little Ice Age maximum, Nature Geosci., 4, 303-307, doi:10.1038/NGEO1122, 2011.

Glazovsky, A., Macheret, Y., Navarro, F., and Vasilenko, E.: Aldegondabreen, Svalbard, available at: http://icemass.narod.ru/ aldegonda.htm, 2009

Granshaw, F. D. and Fountain, A. G.: Gateway to the Glaciers of Mount Rainier, available at: http://www.glaciers.pdx.edu/ Projects/LearnAboutGlaciers/MRNP/index.html, 2009

Gregory, J. M., White, N. J., Church, J. A., Bierkens, M. F. P., Box, J. E., van den Broeke, M. R., Cogley, J. G., Fettweis, X., Hanna, E., Huybrechts, P., Konikow, L. F., Leclercq, P. W., Marzeion, B., Oerlemans, J., Tamisiea, M. E., Wada, Y., Wake, L. M., and van de Wal, R. S. W.: Twentieth-century global-mean sea-level rise: is the whole greater than the sum of the parts?, J.Climate, 26, 4476-4499, doi:10.1175/JCLI-D-12-00319.1, 2013.

Greuell, W.: Hintereisferner, Austria: mass-balance reconstruction and numerical modelling of the historical length variations, J Glaciol., 38, 233-244, 1992.

Hall, D. K., Bayr, K. J., Schöner, W., Bindschadler, R. A., and Chien, J. Y. L.: Consideration of the errors inherent in mapping historical glacier positions in Austria from ground and space (1893-2001), Remote Sens. Environ., 86, 566-577, doi:10.1016/S0034-4257(03)00134-2, 2003.

Hastenrath, S.: The Glaciers of Equatorial East Africa, D. Reidel Publishing Company, P.O. Box 173300 AA Dordrecht, 353 pp., 1983.

Heliker, C. C., Johnson, A., and Hodge, S. M.: The Nisqually glacier, Mount Rainier, Washington, 1857-1979: A summary of the long-term observations and a comprehensive bibliography, US Geological survey, open-file report 83-541, 1984.

Johannesson, T., Bjornsson, H., and Grothendieck, G.: Package 'Stinepack', Icelandic Meteorological Office, 2009.

Kamb, B., Raymond, C. F., Harrison, W. D., Engelhardt, H., Echelmeyer, K. A., Humphrey, N., Brugman, M. M., and Pfeffer, T.: Glacier Surge Mechanism: 1982-1983 Surge of Variegated Glacier, Alaska, Science, 227, 469-479, 1985.

Kaser, G. and Osmaston, H.: Tropical glaciers, Camebridge University Press, http://books.google.com/books? id=ZEB-I3twN_gC\&dq=Kaser+Osmaston+Tropical+ 
Glaciers\&printsec $=$ frontcover $\&$ source $=b n \& h l=e n \& e i=$

3 YrxSvPrC8bd-QaUtankAg\&sa=X\&oi=book_result\&ct= result\&resnum $=4 \& v e d=0$ CBEQ6AEwAw\#v=onepage $\& \mathrm{q}=\& \mathrm{f}=$ false, 2002.

Klok, E. J. and Oerlemans, J.: Climate Reconstructions Derived from Global Glacier Length Records, Arctic, Ant. Alpine Res., 36, 575-583, 2004.

Koch, J. and Kilian, R.: 'Little Ice Age' glacier fluctuations, Gran Campo Nevado, southernmost Chile, The Holocene, 15, 20-28, 2005.

Koch, J., Menounos, B., and Clague, J. G.: Glacier change in Garibaldi Provincial Park, southern Coast Mountains, British Columbia, since the Little Ice Age, Global Planet. Change, 66, 161-178, doi:10.1016/j.gloplacha.2008.11.006, 2009.

Koutnik, M.: University of Washington Research on Blue Glacier, website, 2009.

Laverov, N. P. (ed.): Modern methods of geological-geophysical monitoring over natural processes on the territory of KabardinoBalkaria, KBGU, Nalchik, 2004.

Le Bris, R., Paul, F., Frey, H., and Bolch, T.: A new satellite derived glacier inventory for Western Alaska, Ann. Glaciol., 52, 2011.

Le Quesne, C., Acuña, C., Boninsegna, J. A., Rivera, A., and Barichivich, J.: Long-term glacier variations in the Central Andes of Argentina and Chile, inferred from historical records and tree-ring reconstructed precipitation, Palaeogeogr. Palaeoclim. Palaeoecol., 281, 334-344, 2009.

Leclercq, P. W. and Oerlemans, J.: Global and hemispheric temperature reconstruction from glacier length fluctuations, Clim. Dynam., 38, 1065-1079, doi:10.1007/s00382-011-1145-7, 2012.

Leclercq, P. W., Oerlemans, J., and Cogley, J. G.: Estimating the Glacier Contribution to Sea-Level Rise for the Period 18002005, Surv. Geophys., 32, 519-535, doi:10.1007/s10712-0119121-7, 2011.

Leclercq, P. W., Pitte, P., Giesen, R. H., Masiokas, M. H., and Oerlemans, J.: Modelling and climatic interpretation of the length fluctuations of Glaciar Frías (north Patagonian Andes, Argentina) 1639-2009 AD, Clim. Past, 8, 1385-1402, doi:10.5194/cp-81385-2012, 2012a.

Leclercq, P. W., Weidick, A., Paul, F., Bolch, T., Citterio, M., and Oerlemans, J.: Brief comment: Historical glacier length changes in West Greenland, The Cryosphere, 6, 3491-3501, doi:10.5194/tc-6-1339-2012, 2012b.

Liu, S., Sun, W., Shen, Y., and Li, G.: Glacier changes since the Litlle Ice Age maximum in the western Qilian Shan, northwest China, and consequences of glacier runoff for water supply, J. Glaciol., 49, 117-124, 2003.

López, P., Chevallier, P., Favier, V., Pouyaud, B., Ordenes, F., and Oerlemans, J.: A regional view of fluctuations of glacier length in southern South America, Global Planet. Change, 71, 85-108, doi:10.1016/j.gloplacha.2009.12.009, 2010.

Luckman, B. H.: The Little Ice Age in the Canadian Rockies, Geomorphology, 32, 357-384, doi:10.1016/S0169-555X(99)00104$\mathrm{X}, 2000$.

Lüthi, M. P.: Little Ice Age climate reconstruction from ensemble reanalysis of Alpine glacier fluctuations, The Cryosphere, 8 , 639-650, 2014, doi:10.5194/tc-8-639-2014, 2014.

Lüthi, M. P., Bauder, A., and Funk, M.: Volume change reconstruction of Swiss glaciers from length change data, J. Geophys. Res., 115, F0402, doi:10.1029/2010JF001695, 2010.
Masiokas, M., Luckman, B., Villalba, R., Delgado, S., Skvarca, P., and Ripalta, A.: Little Ice Age fluctuations of small glaciers in Monte Fitz Roy and Lago del Desierto areas, south Patagonian Andes, Argentina, Palaeogeogr. Palaeoclimatol. Palaeoecol., 281, 351-362, doi:10.1016/j.palaeo.2007.10.031, 2009.

McKinzey, K. M., Lawson, W., Keller, D., and Hubbard, A.: A revised Little Ice Age chronology of the Franz Josef Glacier, Westland, New Zealand, J.Royal Soc. New Zealand, 34, 381-394, 2004.

Moore, R. D., Flemming, S. W., Menounos, B., Wheate, R., Fountain, A., Stahl, K., Holm, K., and Jakob, M.: Glacier change in western North America: influences on hydrology, geomorphic hazards and water quality, Hydrol. Proc., 23, 42-61, doi:10.1002/hyp.7162, 2009.

Nesje, A., Dahl, S. O., Thun, T., and Nordli, Ø.: The 'Little Ice Age' glacial expansion in western Scandinavia: summer temperature or winter precipitation?, Clim. Dynam., 30, 789-801, doi:10.1007/s00382-007-0324-z, 2008.

Nick, F. M.: Modelling the behaviour of tidewater glaciers, Ph.D. thesis, IMAU, 2006.

Nussbaumer, S. U. and Zumbühl, H. J.: The Little Ice Age history of the Glacier des Bossons (Mont Blanc massif, France): a new high-resolution glacier length curve based on historical documents, Clim. Change, 111, 301-334, doi:10.1007/s10584011-0130-9, 2012.

Nussbaumer, S. U., Zumbühl, H. J., and Steiner, D.: Fluctuations of the "Mer de Glace" (Mont Blanc area, France) AD 1500 2050: an interdisciplinary approach using new historical data and neural network simulations, Zeitschrift für Gletscherkunde und Glazialgeologie, 40, 1-183, 2007.

Nussbaumer, S. U., Nesje, A., and Zumbühl, H. J.: Historical glacier fluctuations of Jostedalsbreen and Folgefonna (southern Norway) reassessed by new pictorial and written evidence, The Holocene, 21, 455-471, doi:10.1177/0959683610385728, 2011.

Oerlemans, J.: Glaciers and Climate Change, AA Balkema Publishers, Dordrecht, the Netherlands, 148 pp., 2001.

Oerlemans, J.: Extracting a climate signal from 169 glacier records, Science, 308, 675-677, 2005.

Oerlemans, J., Dyurgerov, M., and van de Wal, R. S. W.: Reconstructing the glacier contribution to sea-level rise back to 1850 , The Cryosphere, 1, 59-65, doi:10.5194/tc-1-59-2007, 2007.

Østrem, G., Haakensen, N., and Melander, O.: Glaciological investigations at Nigardsbreen, Norway, Norsk Geografisk Tidsskrift, 30, 187-209, 1977.

Panov, V. D.: Evolution of present-day glacierization of the Caucasus (in Russian), Gidrometeoizdat, St. Petersburg, 1993.

Rabatel, A., Jomelli, V., Naveau, P., Francou, B., and Grancher, D.: Dating of Little Ice Age glacier fluctuations in the tropical Andes: Charquini glaciers, Bolivia, $16^{\circ} \mathrm{S}$, Compt. Rend. Geosci., 337, 1311-1322, 2005.

Rabatel, A., Machaca, A., Francou, B., and Jomelli, V.: Glacier recession on Cerro Charquini $\left(16^{\circ} \mathrm{S}\right)$, Bolivia, since te maximum of the Little Ice Age (17th century), J. Glaciol., 52, 110-118, 2006.

Rabatel, A., Francou, B., Jomelli, V., Naveau, P., and Grancher, D.: A chronology of the Little Ice Age in the tropical Andes of Bolivia $\left(16^{\circ} \mathrm{S}\right)$ and its implications for climate reconstruction, Quat. Res., 70, 198-212, 2008. 
Rachlewicz, G., Szczucinski, W., and Ewertowski, M.: Post-“Little Ice Age" retreat rates of glaciers around Billefjorden in central Spitsbergen, Svalbard, Polish Polar Research, 28, 159-186, 2007.

Salinger, M. J., Heine, M. J., and Burrows, C. J.: Variations of the Stocking (Te Wae Wae) Glacier, Mount Cook, and climatic relationships, New Zealand J. Sci., 26, 321-338, 1983.

Sarikaya, M. A., Zreda, M., and Ciner, A.: Glaciations and paleoclimate of Mount Erciyes, central Turkey, sinc the Last Glacial Maximum, inferred from ${ }^{36} \mathrm{Cl}$ cosmogenic dating and glacier modeling, Quat. Sci. Rev., 28, 2326-2341, doi:10.1016/j.quascirev.2009.04.015, 2009.

Sawaguchi, S., Yamagata, K., Muravyev, Y. D., and Solomina, O. N.: Holocene glacier advances in Koryto Glacier, Kamchatka, Russia, in: Cryospheric studies in Kamchatka II, edited by: Naruse, R., Hara, T., Shiraiwa, T., Sone, T., and Sawagaki, T., 79-84, The Institute of Low Temperature Science, Hokkaido University, 1999.

Schmidt, S. and Nüsser, M.: Fluctuations of Raikot Glacier during the last 70 years: a case study from the Nanga Parbat Massif, Northern Pakistan, J. Glaciol., 55, 949-959, 2009.

Sigurdsson, O.: Glacier variations in Iceland 1930-1995, Jökull, 45, 3-26, 1998.

Solomina, O. N., Ivanov, M., and Bradwell, T.: Lichenometric studies on maraines in the polar Urals, Geograf. Ann., 92A, 81-99, 2010.

Stineman, R. W.: A consistently well-behaved method of interpolation, Creat. Comp., 54-57, 1980.

Taylor, R. G., Mileham, L., Tindimugaya, C., Majugu, A., Muwanga, A., and Nakileza, B.: Recent glacial recession in the Rwenzori Mountains of East Africa due to rising air temperature, Geophys. Rev. Lett., 33, L10402, doi:10.1029/2006GL025962, 2006.

Vieli, A. and Nick, F. M.: Understanding and modelling rapid dynamic changes of tidewater outlet glaciers: issues and implications, Surveys in Geophysics, 32, 437-458, doi:10.1007/s10712011-9132-4, 2011.

Villalba, R., Leiva, J. C., Rubulls, S., Suarez, J., and Lenzano, L.: Climate, tree-ring and glacial fluctuations in the Rio Frias Valley, Rio Negro, Argentina, Arctic Alpine Res., 22, 215-232, 1990.

Weeks, L. S.: Tracking ice marginal changes in south central Alaska using remote sensing and glacial geology, Master's thesis, The College of Wooster, 2011.

Weidick, A.: Observations on some Holocene glacier fluctuations in West Greenland, Meddelelser om Grønland, 165, 202 pp., 1968.
WGMS: Fluctuations of Glaciers 2005-2010 (Vol. X), vol. IX, ICSU (WDS)/IUGG (IACS)/UNEP/UNESCO/WMO, World Glacier Monitoring Service, Zurich, Switzerland, doi:10.5904/wgms-fog-2012-11, 2012 and earlier volumes.

WGMS and NSIDC: World Glacier Inventory, Compiled and made available by the World Glacier Monitoring Service, Zurich, Switserland and the National Snow and Ice Data Center, Boulder CO, USA, Boulder, CO, USA, doi:10.7265/N5/NSIDC-WGI-201202, 1989, updated 2012.

Wiles, G. C. and Calkin, P. E.: Late Holocene, high-resolution glacial chronologies and climate, Kenai Mountains, Alaska, Geological Society of America Bulletin, 106, 281-303, doi:10.1130/0016-7606(1994)106<0281:LHHRGC>2.3.CO;2, 1994.

Wiles, G. C., Barclay, D. J., and Calkin, P. E.: Tree-ring-dated 'Litthe Ice Age' histories of maritime glaciers from western Prince William Sound, Alaska, The Holocene, 9, 163-173, 1999.

Williams Jr., R. S. and Ferrigno, J. G., eds.: Satellite Image Atlas of Glaciers of the World, Irian Jaya, Indonesia and New Zealand, vol. 1386-H, US Geological Survey, 1989.

Yde, J. C. and Knudsen, N. T.: Glaciological features in the initial quiescent phase of Kuannersuit glacier, Greenland, Geografiska Annaler, 87A, 473-485, 2005.

Yde, J. C. and Knudsen, N. T.: 20th-century glacier fluctuations on Disko Island (Qeqertarsuaq), Greenland, Ann. Glaciol., 46, 209214, 2007.

Zeeberg, J. and Forman, S. L.: Changes in glacier extent on north Novaya Zemlya in the twentieth century, The Holocene, 11, 161175, 2001.

Zemp, M., Zumbühl, H. J., Nussbaumer, S. U., Masiokas, M. H., Espizua, L. E., and Pitte, P.: Extending glacier monitoring into the Little Ice Age and beyond, 2011.

Zolotarev, E. A.: Evolution of glaciation of Elbrus, Nauchnii mir, Moscow, 2009.

Zumbühl, H. J.: Die Schwankungen der Grindelwaldgletscher in den historischen Bild- und Schriftquellen des 12. bis 19. Jahrhunderts, Birkhäuser, Basel, 1980.

Zumbühl, H. J. and Holzhauser, H.: Alpengletscher in der Kleinen Eiszeit, vol. 3 of Die Alpen, Schweizerischen Alpen Club, Bern, Switzerland, 1988.

Zuo, Z. and Oerlemans, J.: Contribution of glacier melt to sea-level rise since AD 1865: a regionally differentiated calculation, Clim. Dynam., 13, 835-845, 1997. 